\title{
Virtual Teaching And Strategies: Transitioning From Teaching Traditional Classes To Online Classes
}

Bob Barrett, Franklin University, USA

\begin{abstract}
As more technology has become available in many parts of the globe, a new type of student population has emerged. The traditional student image of higher learning has been somewhat limited in many countries, but given the impact of the Internet, this traditional "student body" has changed. Rather than being limited to regional demographics, the student body for educational institutions offering online courses has changed drastically. In fact, these online courses have started yet another chapter in the history of education, known as virtual learning communities. While online instructors may start out teaching students from local areas, this particular opportunity has been changing over the past decade. In fact, many online instructors have noted an increase in a more diversified student population in their classes. Further, they have realized the need to update their teaching skills, practices and strategies in order to accommodate the changing needs of the learners in the classroom, as well as updating their own teaching portfolio. This paper will provide a brief overview of current recruitment and hiring methods used in the traditional hiring versus online hiring of educators. Also, this paper will address the growing concerns of current traditional teachers as they approach the decision to transition over to online learning and how to obtain proper online instruction. Finally, this paper will overview how one online university has approached online teacher training for both experienced instructors, as well as new teaching recruits as they prepare to transition from traditional classrooms over to virtual classes.
\end{abstract}

Keywords: Virtual learning; teachings strategies; traditional learning; online learning; online teaching strategies; online teacher training; teacher training

\section{INTRODUCTION}

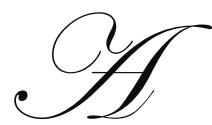

s more technology has become available in many parts of the globe, a new type of student population has emerged. The traditional student image of higher learning has been somewhat limited in many countries, but given the impact of the Internet, this traditional "student body" has changed. Rather than being limited to regional demographics, the student body for educational institutions offering online courses has changed drastically. In fact, these online courses have started yet another chapter in the history of education, known as virtual learning communities.

- In 2008, Sloan Consortium reports that there are approximately 4 million college students are currently enrolled in fully online courses.

- In 2006, Sloan Consortium reported there were 3.2 million postsecondary students in the United States that took at least one online course; this represents a $25 \%$ increase over the previous year. (http://www.nacol.org).

Further, there is also a growing need for online instruction in the K-12 market. 
- $\quad \mathrm{K}-12$ online learning is a new field consisting of an estimated $\$ 300$ million market, which is growing at an estimated annual pace of $30 \%$ annually.

- „45 of the 50 states, plus Washington D.C., have a state virtual school or online initiative, full-time online schools, or both.

- $\quad$,24 states, as well as Washington, DC, have statewide full-time online schools.

- $\quad$ Many virtual schools show annual growth rates between 20 and $45 \%$.

- $\quad 35$ states have state virtual schools or state-led online programs. (http://www.nacol.org).

While online instructors may start out teaching students from local areas, this particular opportunity has been changing over the past decade. In fact, many online instructors have noted an increase in a more diversified student population in their classes. Further, they have realized the need to update their teaching skills, practices and strategies in order to accommodate the changing needs of the learners in the classroom, as well as updating their own teaching portfolio.

Teaching business and management has changed over the past decades in terms of the types of delivery, especially with the use of technology. The use of online learning has helped to increase student enrollments, diversify the variety of student input and perspectives, as well as increase the exposure of instructors to bigger learning demands of the learners. As a result, virtual instructors today need to develop and enhance their teaching strategies and methodologies in order to meet the growing needs of today's online learning population. No longer are instructors focusing on teaching just local learners, but they must also concentrate on teaching students from a variety of international locations.

This paper will focus on transitioning new and current instructors teaching in a live classroom setting to prepare them to teach online. The online learning environment differs from the physical, live classroom setting in terms of student population, use of technology, and vast ranges of time zones shared by a variety of students in an online course. As a result, it is important for adequate and appropriate online training/instruction be afforded to this specific population of educators.

\section{PURPOSE}

Due to the technological advancements in the online environment, online instructors must have a different type of skills sets in order to compete in today's online learning environment. As a result, interviewers and HR personnel must create and implement different practices and procedures in order to determine the best possible candidate for an online teaching position. Thus, this paper will help to provide an open forum for the audience to determine if there is a need for change.

Currently, recruiting and hiring methods used in the traditional hiring versus online hiring of educators do differ. When organizations are seeking qualified personnel to teach for their educational institutions, they may also need to gather and assess more information in order to best determine which candidate best "fits" the needs of the organization and position. As a result, there is a growing need for interviewers to capture more substantial data in order to help assist others in the hiring process. Further, they may need to employ different methods for recruiting and hiring. A new type of employee is needed to fill online instructional positions, so candidates must have certain skills sets.

While many traditional instructors enjoy teaching in a live, physical classroom, many are starting to consider the possibility of transitioning over to online learning and how to obtain proper online instruction. Due to the lack of classroom space and declining enrollments, many colleges and universities have started to consider and implement online learning courses and programs. As a result, they have been changing their traditional approach to teacher training to that of an online learning environment. This change has been quite effective since many traditional instructors have been considering or have been assigned to teach online courses. While there is still a large population of graduates who have learned in the traditional learning environment (on-ground classes), there is a growing number of adult learners obtaining their degrees from online universities (with the same type of accreditation as their on-ground counterparts). As a result, both online and on-ground graduates are now seeking additional education in order to compete for online (adjunct) teaching opportunities. 
While distance education has been happening over the past 3-4 decades, the evolution of online learning has been growing rapidly in the higher education field. As this field has been seeing more and more online programs appear, many of the administrative and training departments of various colleges and universities have realized the need to help current and potential online instructors in preparing for online teaching in terms of current teaching strategies used - both from the live (on-ground) environment, as well as those strategies used in the online learning environment. Many colleges and universities now recruit, hire, and train potential online instructors via the Internet in terms of their electronic postings of jobs.

There are four major areas that many universities must consider in the area of instructor recruitment and hiring. First, they need to reconsider their approach to recruitment, hiring, and training of current and future instructors for employment in the area of the online teaching. Second, they need to look the best practices of other leading educational institutions to see how they are conducting their recruitment and training of online instructors. Third, they need to update their technological and skill requirements for online instructors to make sure that they are hiring the best for their educational institution. . Barbara Smith (2000), chief learning officer for Burson-Marsteller stated that "If we don't have the best people creating the best product, we can't compete. What I'm after is creating the best people in the industry. E-learning is an option that provides us with a real competitive edge-it helps us maximize our intellectual capital" (para. 2). During this process, these educational institutions should examine the potential networking efforts, which could be possible for current and potential online instructors to meet others interested in online teaching during these instructional workshops, seminars, or courses. The following section will discuss the issues of recruitment and hiring. In particular, a discussion will be held on the characteristics of online instructor. Finally, there will be a brief overview of the online teacher training.

\section{RECRUITMENT AND HIRING OF POTENTIAL ONLINE INSTRUCTORS}

When organizations are seeking qualified personnel to teach for their educational institutions, they may also need to gather and assess more information in order to best determine which candidate best "fits" the needs of the organization and position. As a result, there is a growing need for interviewers to capture more substantial data in order to help assist others in the hiring process. Further, they may need to employee different methods for recruiting and hiring. Due to the technological advancements in the online environment, online instructors must have a different type of skills sets in order to compete in today's online learning environment. As a result, interviewers and HR personnel must create and implement different practices and procedures in order to determine the best possible candidate for an online teaching position.

\section{CHARACTERISTICS OF AN ONLINE INSTRUCTOR}

What are the characteristics of a good and bad online instructor? Roueche, Roueche, and Milliron (1995) stated, "Adjunct faculty are increasingly important players in the teaching and learning process. It is in the college's best interest of appreciating the investment value of them, and ultimately in the interest of establishing and maintaining the college's reputation for teaching excellence" (p. 120). As noted early, many online teaching positions are being filled by part-time instructors. Many colleges and universities have found that this helps to reduce some administration of benefits and pay - so part-time faculty have been a "quick fix" for their current need. However, it should be noted for the purposes of this paper that there may be a change in this situation within the next decade or two as more part-time faculty seek more pay and benefits (i.e., union organization).

\section{TRAINING INSTRUCTORS ONLINE}

While some teaching tools may be effective in one learning environment, they may not be as successful in another. Therefore, as each environment is unique, as well as the learners in it, the teacher needs to assess their virtual environment and determine if change is necessary. However, not all educators may be as flexible in their teaching method, and they may not be willing to change. This leads us to the following question. Do educators incorporate different teaching strategies and techniques to meet the ever-changing needs of these virtual learners in terms of learning from their cultural differences in order to enhance the learning experiences of all? 
While we may hope that all educators are continuously improving their teaching methods and classrooms, we must recognize the fact that some may not. In the traditional classroom, there was an "expected" structure of teaching and layout of the classroom. However, in the virtual learning environment, educators have had to "unlearn" their old way of thinking in terms of teaching methodologies. In turn, online educators have had to learn new ways of implementing and nurturing learning for their virtual student populations. The key to success is our ability to think, visualize, and implement. White (2002) noted "Nowhere is thinking more evident than in the textual environment of the online classroom. If writing is thinking, then online students display their thinking throughout the course, illustrating their individual styles and changing attitudes." (p. 6) Along this same line of thinking, educators can incorporate various strategies to help draw upon the experiences of all class members - rather than just a select few.

\section{CONCLUSION}

Traditionally, teachers have been expected serve as role models as they lead classroom discussions, collected and graded assignments, and provide leadership and guidance to their students. However, over the past two decades, the role and function of the instructor has changed drastically due to economic, technological, and educational factors. In any event, the area of online instruction has started to attract more and more students, as well as more instructors. In order to meet this growing demand for better qualified, online instructors, many schools have had to rethink their recruiting, hiring, and training efforts. Thus, there is a growing need to offer better quality online teacher training to current and potential online instructors to better enable these instructors to meet the everchanging need of their online learning populations.

\section{AUTHOR INFORMATION}

Dr. Bob Barrett received his Ed.D. at The George Washington University; his M.B.E. at The University of the District of Columbia; and his B.A. at Shepherd University. He has completed additional Studies at University of Maryland - College Park, USDA Graduate School, and Gallaudet University. Dr. Barrett's current research interests are: Human Resource Development (HRD); Human Resource Management (HRM); Virtual Management Teams; Stakeholder Theory/Ethics; Logic/Dominant Logic; Disability/BDEP.

\section{REFERENCES}

1. $\quad$ NACOL. http://www.nacol.org. Retrieved June 15, 2009.

2. National Center for Education Statistics, 2003.

3. Preece, J. (2000). Online communities: Designing usability, supporting sociability. Chichester: Wiley.

4. $\quad$ Roueche, J.E., Roueche, S.D., and Milliron, M.D. (1995). Strangers in their own land: Parts-time faculty in American's community colleges. Washington D.C.: Community College Press.

5. Smith, B. (2000). Online Learning: The Competitive Edge: Companies blend E-learning into their business strategies to maximize intellectual capital. InformationWeek.com Retrieved September 22, 2010, http://www.informationweek.com/801/learn.htm.

6. White, K.W., Weight, B.H. (2000). The online teaching guide: A handbook of attitudes, strategies, and techniques for the virtual classroom. Needham Heights, MA: Allyn \& Bacon. 